Wahana Didaktika Vol. 18 No.3 September 2020 : 236-246

\title{
ANALISIS KEMAMPUAN SISWA DALAM MENYELESAIKAN SOAL JURNAL UMUM DI SMK NEGERI 1 BENAKAT
}

\author{
Oleh: Dian Junia Putri ${ }^{1}$, Bukman Lian', Riswan Aradea ${ }^{3}$ \\ (SMK Negeri 1 Benakat ${ }^{1}$, Universitas PGRI Palembang, ${ }^{2,3}$,) \\ Email: Dianjuniaputri13@gmail.com
}

\begin{abstract}
Abstrak
Tujuan penelitian ini adalah untuk mengetahui kemampuan siswa dalam menyelesaikan soal jurnal umum pada mata pelajaran praktikum akuntansi perusahaan jasa di SMK Negeri 1 Benakat tahun pelajaran 2019/2020. Metode penelitian yang digunakan adalah metode deskriptif dengan pendekatan kuantitatif. Hasil penelitian menunjukan bahwa sebanyak 40 siswa dengan interval (86-100) persentase 56\% dengan kategori "Baik sekali", dan sebanyak 21 siswa interval (71-85) persentase 30\% dengan kategori "Baik" serta sebanyak 6 siswa interval (56-70) dengan persentase 8\% dengan kategori "Cukup" 2 siswa interval (41-55) dengan persentase 3\% kategori "Kurang" serta 2 siswa dengan interval (<40) persentase 3\% pada kategori "Kurang Sekali". Dan Nilai ratarata untuk seluruh siswa kelas XI Akuntansi kemampuan siswa dalam menyelesaikan soal jurnal umum adalah sebesar 83,90 pada kategori "Baik".maka dapat dinyatakan bahwa siswa kelas XI Akuntansi mampu dalam menyelesaikan soal jurnal umum pada kategori "Baik".
\end{abstract}

Kata Kunci : Kemampuan Siswa, Jurnal Umum

\section{ANALYSIS OF STUDENT'S ABILITY IN COMPLETING GENERAL JOURNAL PROBLEMS AT VOCATIONAL SCHOOL 1 BENAKAT}

\begin{abstract}
The purpose of this study was to determine the ability of students to solve general journal questions in the subject matter of practicum accounting in the State Vocational School 1 Benakat academic year 2019/2020. The research method used is a descriptive method with a quantitative approach. The results showed that as many as 40 students with intervals (86-100) percentage of 56\% with the category "Very Good", and as many as 21 interval students (71-85) the percentage of $30 \%$ with the category "Good" and as many as 6 interval students (56- 70) with a percentage of $8 \%$ with the category "Fair" 2 interval students (41$55)$ with a percentage of $3 \%$ the category "Less" and 2 students with an interval (<40) percentage of $3 \%$ in the category "Very Less". And the average value for all students of class XI Accounting students' ability to solve general journal questions is 83.90 in the "Good" category. So it can be stated that students of class XI Accounting are able to solve general journal questions in the "Good" category.
\end{abstract}

Keywords: Students Ability, General Journal 


\section{A. PENDAHULUAN}

Pendidikan merupakan hal yang sangat penting bagi perkembangan pola pikir manusia untuk membangun bangsa. Di era globalisasi sekarang ini, kita telah mengetahui bahwa dunia telah banyak mengalami perubahan dan kemajuan di bidang ilmu pengetahuan dan pendidikan. Dalam hal ini pendidikan memegang peranan yang sangat penting, karena dengan pendidikanlah dapat dicetak tenagatenaga kerja yang ahli dan profesional.

Pendidikan merupakan kebutuhan yang harus dipenuhi setiap individu sepanjang hayat. Tanpa pendidikan, sama sekali mustahil sekelompok individu dapat hidup berkembang sejalan dengan cita-cita untuk maju, sejahtera dan bahagia. Di dalam proses belajar mengajar akan terdapat interaksi antara pendidik dan siswa maka interaksi tersebut haruslah berjalan dengan baik guna mencapai hasil yang optimal sesuai dengan yang diharapkan. Siswa perlu memiliki kemampuan memperoleh, menganalisis, memiliki, dan mengelola informasi untuk bertahan pada keadaan yang selalu berubah, tidak pasti dan kompetitif.

Jurnal umum adalah buku harian yang digunakan untuk mencatat semua transaksi yang terjadi dalam satu periode yang berupa pendebitan dan pengkreditan secara kronologis. Aktivitas yang dilakukan siswa di saat melakukan pencatatan atau mempelajari jurnal umum menekankan pada pemahaman dan keterampilan, yang berarti kemampuan siswa dalam menggunakan daya fikir dan kemampuan tersebut mencakup kemampuan kognitif yang juga merupakan kemampuan berfikir meliputi kemampuan, mengingat, memahami, menerapkan, menganalisis, mengevaluasi, dan menciptakan.

Aktivitas mempelajari bahan belajar mempunyai jenis dan sifat bahan serta tergantung pada kemampuan siswa dalam memahaminya. Kemampuansiswa itu pada dasarnya berbeda-beda ada yang cepat memahami dan justru ada yang sebaliknya. Dari observasi yang didapatkan peneliti di SMK Negeri 1 Benakat bahwa siswa dalam praktiknya masih ada yang belum mampu dalam menganalisis soal jurnal umum karena siswa masih ada bingung membedakan nama akun yang termasuk dalam akun aktiva dan akun passiva, karena siswa cenderung menghafal bukan memahami akun-akun apa yang saja yang akan muncul dalam menganalisis 
soal jurnal umum, kurangnya latihan dan kurang memahami materi karena metode mengajar guru yang kurang dipahami oleh siswa.

Putri (2012:3) "Kebanyakan orang mengira belajar adalah menghafal. Kenyataanya orang hafal belum tentu paham tetapi orang yang sudah paham pasti mengerti, pada disiplin ilmu akuntansi ini siswa dituntut untuk memahami bukan sekedar menghafal materi yang diajarkan, Siswa harus memiliki pemahaman atau kemampuan menganalisis sehingga siswa bisa membaca sebuah transaksi karena setiap transaksi akan di kelompokkan sesuai nama akun yang ada sesuai dengan penempatan debit dan kredit, sebab membaca transaksi tidaklah mudah karena butuh ketelitian yang kuat serta pehamahan yang benar, maka dalam praktiknya siswa harus terus latihan dan menanamkan konsep pendebitan dan pengkreditan”.

Berdasarkan permasalahan yang didapat dari penjelasan di atas, maka yang jadi masalah dalam penelitian ini adalah "Bagaimanakah Kemampuan Siswa Dalam Menyelesaikan Soal Jurnal Umum Pada Mata Pelajaran Praktikum Akuntansi Perusahan Jasa di SMK Negeri 1 Benakat Tahun Pelajaran 2019/2020". Tujuan penelitian ini adalah untuk mengetahui Kemampuan siswa dalam menyelesaikan soal jurnal umum pada mata pelajaran praktikum akuntansi perusahaan jasa di SMK Negeri 1 benakat tahun pelajaran 2019/2020.

Ibeng (2019) analisis ialah aktivitas atau kegiatan yang melingkupi beberapa aktivitas. Aktivitas-aktivitas tersebut berupa membedakan, mengurai, serta juga memilah-milih untuk bisa dimasukan ke dalam kelompok tertentu atau dikategorikan dengan tujuan-tujuan tertentu. Hingga akhirnya harus mencari kaitan antara hal-hal tersebut serta juga menterjemahkan arti tersebut. Anggel (2017:39) "belajar adalah proses ketika seseorang memperoleh berbagai kecakapan, keterampilan, dan sikap, Belajar dimulai pada masa ketik bayi memperoleh sejumlah kecil keterampilan yang sederhana, seperti belajar memegang botol susu dan mengenal ibunya".

Sudiro (2018:3-4) kemampuan adalah sebuah penilaian saat ini atas apa yang bisa dilakukan seseorang. Kemampuan keseluruhan individu pada dasarnya terdiri atas dua faktor, yaitu intelektual dan fisik. Kemampuan intelektual dibutuhkan untuk melakukan berbagai aktivitas mental, berpikir, penalaran, dan 
pemecahan masalah. Kebanyakan masyarakat cenderung menempatakan nilai tertinggi pada kecerdasan, kemampuan fisik untuk tingkat yang sama bahwa kemampuan intelektual memainkan peran lebih besar dalam pekerjaan yang kompleks dengan tuntutan persyaratan kebutuhan pemrosesan informasi.

Bloom dikutip dalam Gunawan (2012:26-29) taksonomi bloom ranah kognitif yang telah direvisi Anderson yakni : mengingat (Remember), (1) Memahami (Understand), (2) Menerapkan (Apply), (3) Menganalisis (Analyze), (4) Mengevaluasi (Evaluate), dan (5) Menciptakan (Create). Menurut Namira (2018:2) “akuntansi adalah suatu seni (dikatakan seni karena perlu kerapian, ketelitian, kebersihan) pencatatan, penggolongan, peringkasan, dan pelaporan dengan cara yang baik dalam unit moneter atas transaksi-transaksi keuangan dan kejadian-kejadian lain sehubung dengan keuangan perusahaan dan menafsirkan hasil-hasil pencatatan tersebut".

\section{B. METODOLOGI PENELITIAN}

Metode penelitian yang digunakan adalah deskriftif dengan pendekatan kuantitatif, karena penelitian ini menggmbarkan atau memaparkan keadaan sesuai dengan fakta yang yang digambarkan dengan angka-angka dan dipisahkan menurut kelompok atau kategori untuk memperoleh kesimpulan. Objek dalam penelitian adalah seluruh kelas XI Akuntansi semester ganjil sebanyak 71 siswa terdiri dari kelas XI Akuntansi 1,2 dan 3 SMK Negeri 1 Benakat tahun pelajaran 2019/2020.

Teknik pengumpulan data yang digunakan adalah dokumentasi dan tes. Dimana tes yang diberikan berupa soal-soal jurnal umum bentuk transaksi dan bukti transaksi. Kemudian dilakukan pengumpulan data. Teknik analisis yang digunakan dalam penelitian ini menggunakan:

1. Menilai hasil tes dengan mengubah skor -skor jawaban yang didapat oleh siswa dengan pernyataan sebagai berikut:

$$
N A=\frac{\text { Jumlah skor yang diperoleh }}{\text { Jumlah skor maksimal }} x 100 \quad \text { (Arikunto, 2017:272) }
$$


Untuk melihat tercapai atau tidaknya proses belajar mengajar dan keberhasilan siswa, ada kriteria yang harus dilihat dalam menilai hasil belajar. Adapun indikator keberhasilan siswa di sekolah dalam penelitian ini dalam tabel berikut :

Kategori Nilai Hasil Belajar

\begin{tabular}{|c|c|c|c|}
\hline No & Interval Nilai & Nilai Huruf & Kategori \\
\hline 1 & $86-100$ & A & Baik Sekali \\
\hline 2 & $71-85$ & B & Baik \\
\hline 3 & $56-70$ & C & Cukup \\
\hline 4 & $55-41$ & D & Kurang \\
\hline 5 & $<40$ & E & Kurang Sekali \\
\hline
\end{tabular}

2. Menghitung rata-rata kemampuan siswa. Untuk menghitung rata-rata nilai siswa digunakan rumus sebagai berikut :

$$
\text { Rata }- \text { rata }=\frac{\text { Total Nilai }}{\text { Jumlah Sampel }}
$$

3. Menganalisis persentase siswa pada tiap kriteria penilaian baik indikator soal maupun keseluruhan soal.

$$
P=\frac{F}{n} \times 100
$$

Keterangan :

$\mathrm{P} \quad=$ Angka persentase

(besarnya persentase siswa pada tiap kriteria)

$f \quad=$ Frekuensi yang sedang dicari persentasenya

(Frekuensi siswa tiap soal)

$\mathrm{n} \quad=$ Number Of Cases (jumlah frekuensi/banyaknya individu) (jumlah siswa yang menjadi sampel)

4. Menganalisis tiap butir soal dengan tingkat kesulitan soal menggunakan rumus :

$$
I=\frac{B}{N} \quad(\text { Sudjana, 2012:137) }
$$


I = Indeks Kesulitas setiap soal

B = Banyaknya siswa yang menjawab benar setiap butir soal

$\mathrm{N}$ = Banyaknya siswa yang meberikan jawaban pada soal yang dimaksudkan

Kriteria indeks kesulitan soal itu adalah sebagai berikut :

$0-0,30=$ Soal kategori sukar

$0,31-0,70=$ Soal kategori sedang

$0,71-1,00=$ Soal kategori mudah

\section{HASIL PENELITIAN DAN PEMBAHASAN}

1. Menilai hasil siswa dan Melihat hasil rata-rata kemampuan siswa untuk seluruh kelas XI AK 1,2 dan 3.

Rata - rata $=\frac{5.957}{71}=83,90$

Persentase Nilai Keseluruhan Siswa Kelas XI Akuntansi

\begin{tabular}{|c|c|c|c|}
\hline Interval Nilai & Frekuensi (F) & Persentase & Kategori \\
\hline $86-100$ & 40 & $\frac{40}{71} \times 100=56 \%$ & Baik Sekali \\
\hline $71-85$ & 21 & $\frac{21}{71} \times 100=30 \%$ & Baik \\
\hline $56-70$ & 6 & $\frac{10}{71} \times 100=8 \%$ & Cukup \\
\hline $41-55$ & 2 & $\frac{2}{71} \times 100=3 \%$ & Kurang \\
\hline$<40$ & 2 & $\frac{2}{71} \times 100=3 \%$ & Kurang Sekali \\
\hline$\sum$ & 71 & 100 & - \\
\hline
\end{tabular}

Berdasarkan tabel 1 persentase nilai keseluruhan siswa kelas XI Akuntansi dalam menyelesaikan soal jurnal umum dapat dilihat dari tabel persentase kategori "Baik sekali" sebanyak 40 siswa dengan persentase 56\%, kategori "Baik" sebanyak 21 siswa dengan persentase 30\%, dan pada kategori "Cukup" sebanyak 6 siswa dengan persentase $8 \%$ dan sebanyak 2 siswa dengan persentase $3 \%$ pada 
kategori "Kurang" 2 siswa persentase 3\% "Kurang sekali”. Dapat dilihat pada diagram di bawah ini:

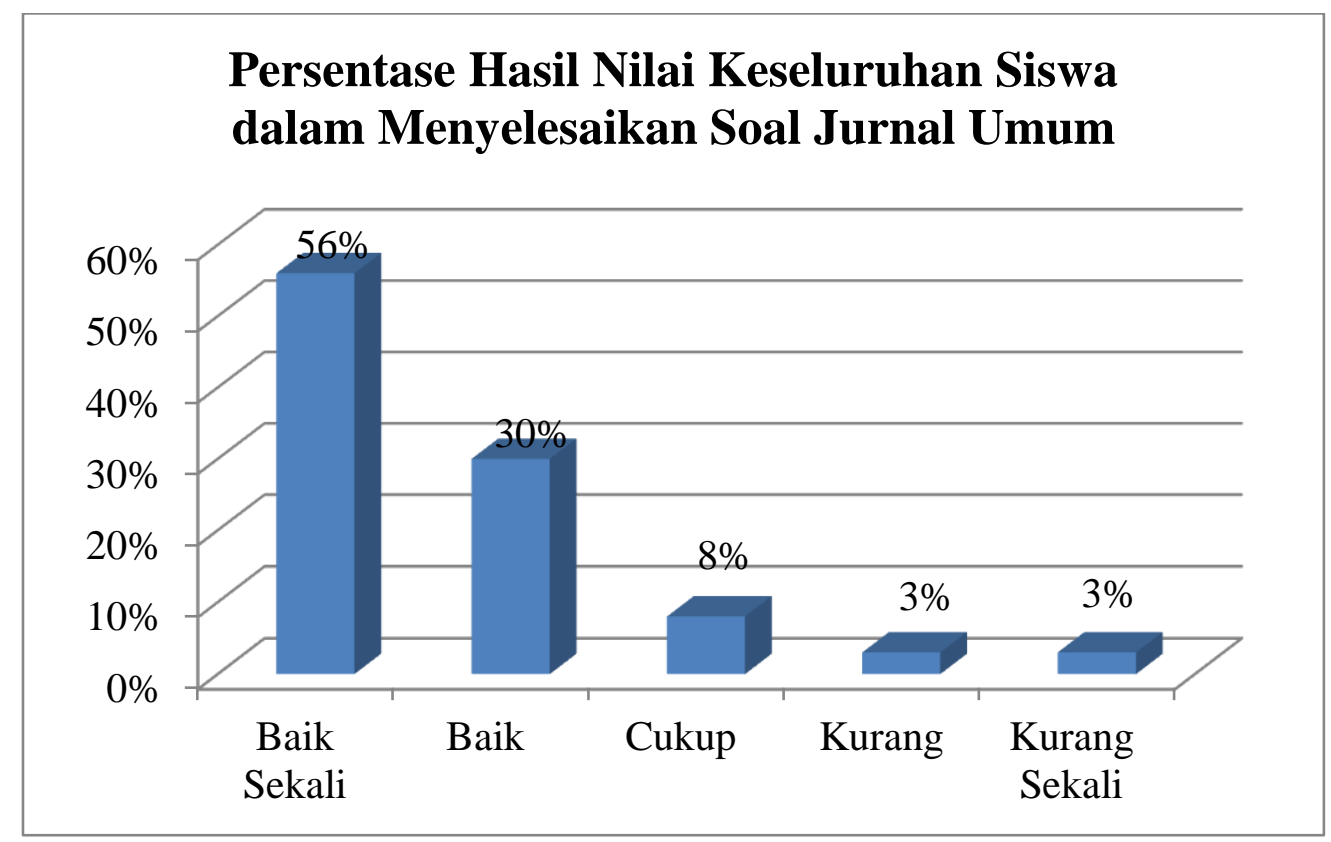

Menganalisis Tiap Butir Soal Dengan Tingkat Kesulitan

\begin{tabular}{|c|l|c|c|c|}
\hline $\begin{array}{c}\text { Tanggal } \\
\text { Transaksi }\end{array}$ & \multicolumn{1}{|c|}{ Soal Tes } & $\begin{array}{c}\text { Freku- } \\
\text { ensi }\end{array}$ & $\begin{array}{c}\text { Indeks } \\
\text { Kesukaran } \\
\text { soal }\end{array}$ & $\begin{array}{c}\text { Tingkat } \\
\text { kesulitan } \\
\text { soal }\end{array}$ \\
\hline 1 & $\begin{array}{l}\text { Mengenai Modal dan } \\
\text { peralatan }\end{array}$ & 68 & 0,95 & Mudah \\
\hline 2 & $\begin{array}{l}\text { Mengenai peralatan dan } \\
\text { perlengkapan dan utang }\end{array}$ & 64 & 0,90 & Mudah \\
\hline 3 & $\begin{array}{l}\text { Mengenai pendapatan jasa } \\
\text { Mengenai beban listrik }\end{array}$ & 56 & 0,71 & Mudah \\
\hline 4 & $\begin{array}{l}\text { yang harus dibayar } \\
\text { utang iklan dan }\end{array}$ & 60 & 0,84 & Mudah \\
\hline 7 & $\begin{array}{l}\text { Mengenai pendapatan jasa } \\
\text { Mengenai pembelian }\end{array}$ & 51 & 0,71 & Mudah \\
\hline 8 & \begin{tabular}{l} 
peralatan secara tunai \\
\hline
\end{tabular}
\end{tabular}


Analisis Kemampuan Siswa.... (Dian Junia Putri, Bukman Lian, Riswan Aradea)

\begin{tabular}{|c|l|c|c|c|}
\hline $\begin{array}{c}\text { Tanggal } \\
\text { Transaksi }\end{array}$ & \multicolumn{1}{|c|}{ Soal Tes } & $\begin{array}{c}\text { Freku- } \\
\text { ensi }\end{array}$ & $\begin{array}{c}\text { Indeks } \\
\text { Kesukaran } \\
\text { soal }\end{array}$ & $\begin{array}{c}\text { Tingkat } \\
\text { kesulitan } \\
\text { soal }\end{array}$ \\
\hline 9 & Mengenai pelusan utang & 55 & 0,77 & Mudah \\
\hline 10 & $\begin{array}{l}\text { Mengenai pemebelian } \\
\text { secara kredit }\end{array}$ & 44 & 0,61 & Sedang \\
\hline 11 & $\begin{array}{l}\text { Mengenai beban air dan } \\
\text { telpon yang harus dibayar }\end{array}$ & 62 & 0,87 & Mudah \\
\hline 12 & $\begin{array}{l}\text { Mengenai prive } \\
\text { (pengambilan uang) }\end{array}$ & 70 & 0,98 & Mudah \\
\hline 14 & Mengenai pelunasan utang & 52 & 0,73 & Mudah \\
\hline 18 & Mengenai pembelian & 41 & 0,57 & Sedang \\
\hline 20 & perlengkapan secara tunai & & & Mudah \\
\hline 21 & Mengenai beban sewa yang & 40 & 0,56 & Sedang \\
\hline harus dibayar & Mengenai pendapatan jasa & 51 & 0,71 & Mudah \\
\hline 25 & $\begin{array}{l}\text { Mengenai pembelian secara } \\
\text { kredit }\end{array}$ & 36 & 0,50 & Sedang \\
\hline harus dibayar & 65 & 0,91 & \\
\hline
\end{tabular}

Uraian mengenai kemampuan siswa dalam menjawab soal diukur pada setiap butir soal sebagai berikut:

1. Butir soal transaksi tanggal 1 mengenai modal, peralatan salon, sebanyak 68 siswa yang menjawab benar dengan kategori mudah pada indeks 0,95.

2. Butir soal transaksi tanggal 2 mengenai akun peralatan, perlengkapan dan utang usaha, sebanyak 64 siswa yang menjawab benar dengan kategori mudah pada indeks 0,90 .

3. Butir soal transaksi tanggal 3 mengeanai pendapatan jasa, sebanyak 59 siswa yang menjawab benar dengan kategori mudah pada indeks 0,83 . 
4. Butir soal transaksi tanggal 4 mengenai beban listrik yang harus dibayar, sebanyak 56 siswa yang menjawab benar dengan kategori mudah pada indeks 0,78 .

5. Butir soal transaksi tanggal 6 mengenai beban iklan dan utang usaha, sebanyak 60 siswa yang menjawab benar dengan kategori mudah pada indeks 0,84 .

6. Butir soal transaksi tanggal 7 mengenai pendapatan jasa, sebanyak 57 siswa menjawab dengan benar dengan kategori mudah pada indeks 0,8 .

7. Butir soal transaksi 8 mengenai pembelian peralatan secara tunai, (Nota kontan) sebanyak 51 siswa yang menjawab benar dengan kategori mudah pada indeks 0,71

8. Butir soal transaksi 9 mengenai pelunasan utang usaha, sebanyak 55 siswa yang menjawab benar dengan kategori mudah pada indeks 0,77 .

9. Butir soal transaksi tanggal 10 mengenai pembelian secara kredit, sebanyak 44 siswa yang menjawab benar dengan kategori sedang pada indeks 0,61.

10. Butir soal transaksi tanggal 11 mengenai beban air dan telpon yang harus dibayar, sebanyak 62 siswa siswa yang menjawab dengan benar dengan kategori mudah pada indeks 0,87 .

11. Butir soal transaksi tanggal 12 mengenai prive, sebanyak 70 siswa menjawab benar dengan kategori mudah pada indeks 0,98.

12. Butir soal transaksi tanggal 14 mengenai pelunasan utang usaha, sebanyak 52 siswa menjawab benar dengan kategori mudah pada indeks 0,73 .

13. Butir soal transaksi tanggal 18 mengenai pembelian perlengkapan secara tunai, sebanyak 41 siswa menjawab benar dengan kategori sedang pada indeks 0,57 .

14. Butir soal transaksi tanggal 20 mengenai beban sewa yang harus dibayar, sebanyak 40 siswa menjawab benar dengan kategori sedang pada indeks 0,56.

15. Butir soal transaksi tanggal 21 mengenai pendatan jasa, sebanyak 51 siswa menjawab benar dengan kategori mudah pada indeks 0,71 .

16. Butir soal transaksi tanggal 25 pembelian secara kredit (Faktur), sebanyak 36 siswa menjawab benar dengan kategori sedang pada indeks 0,50 . 
17. Butir soal transaksi tanggal 30 mengenai beban gaji yang harus dibayar, sebanyak 65 siswa menjawab benar dengan kategori mudah pada indeks 0,91.

Pada tabel 2 dan uraian di atas tes analisis butir soal bahwa terdapat tingkat kesukaran soal pada kategori sukar pada indeks 0-0,30 bahwa tidak soal yang sukar, selanjutnya kategori sedang pada indeks $0,31-0,70$ soal pada tanggal 10, 18, 20, 25 dan untuk kategori mudah dengan indeks $0,71-1,0$ soal pada tanggal 1, 2, 3, 4, 6, 7, 8, 9, 11, 12, 14, 21, 30.

Berdasarkan penelitian ini telah didapatkan sebanyak 71 siswa dengan hasil sebanyak 40 siswa dengan interval (86-100) persentase 56\% dengan kategori "Baik sekali", dan sebanyak 21 siswa interval (71-85) persentase 30\% dengan kategori "Baik" serta sebanyak 6 siswa interval (56-70) dengan persentase 8\% dengan kategori "Cukup" 2 siswa interval (41-55) dengan persentase 3\% kategori "Kurang" serta 2 siswa dengan interval $(<40)$ persentase 3\% pada kategori "Kurang Sekali". Dan Nilai rata-rata untuk seluruh siswa kelas XI AK kemampuan siswa dalam menyelesaikan soal jurnal umum adalah sebesar 83,90 pada kategori "Baik”.maka dapat dinyatakan bahwa siswa kelas XI mampu dalam menyelesaikan soal jurnal umum pada kategori "Baik".

\section{SIMPULAN}

Dari hasil penelitian dan pembahasan yang telah dilakukan, maka dapat diambil kesimpulan bahwa pemahaman siswa (mengetahui, menunjukan, menentukan dan menganalisis) siswa kelas XI Akuntansi masih ada yang belum mampu menujukkan saldo normal akun serta menganalisis soal transaksi maupun bukti transaksi. Siswa untuk memperbanyak latihan mengenai soal-soal atau transaksi jurnal umum pada mata pelajaran praktikum akuntansi perusahan jasa di SMK Negeri 1 Benakat, dan cara mengajar guru yang harus diperhatikan untuk mencapai tujuan belajar. 


\section{DAFTAR PUSTAKA}

Anggel, F. (2017). Teori Belajar dan Pembelajaran Implementasinya dalam Pembelajaran Bahasa Indonesia di SMP,SMA dan SMK. Yogyakarta: CV Budi Utama.

Arikunto, S. (2017). Dasar-Dasar Evaluasi Pendidikan Edisi 2 . Jakarta: Bumi Aksara.

Gunawan, Palupi. (2012). Taksonomi Bloom Revisi Ranah Kognitif Kerangka Landasan Untuk Pembelajaran, Pengajaran, dan Penilaian. Jurnal Pendidikan Dasar dan Pembelajaran Volume 2 Nomor 2 (Online) http://ejournal.unipma.ac.id/index.php/PE/articel/view/50 (diaskes 16 Januari 2020)

Ibeng, P. (2019). Pengertian Analisis (Online) http://pendidikan.co.id/pengertiananalisis/ (diaskes 19 Januri 2020).

Putri, P, M. (2012). Kemampuan Siswa Menganalisis Jurnal Umum dan Memindahkan ke Buku Besar di Kelas XI IPS Pada Mata Pelajaran Akuntansi di SMA Plus Binabangsa Pekanbaru. Skripsi Thesis Universitas Islam Negeri Sultan Syarif Kasim. (Online) http://repository.uinsuska.ac.id/8237/ (diaskes 16 Januari 2020).

Sudijono, A. (2011). Pengantar Statistik Pendidikan . Jakarta: PT Raja Grafindo Persada.

Sudiro, A. (2018). Prilaku Organisasi. Jakarta: Bumi Aksara.

Sudjana, N. (2012). Penilaian Hasil Belajar Proses Belajar Mengajar. Bandung: PT Remaja Rosdakaya. 